\title{
THE APPLICATION OF SOVEREIGN BOND SPREADS: THE CASE OF SELECTED EU COUNTRIES AND THE USA
}

\author{
[Využití výnosové křivky státních dluhopisů: př́ípad vybraných zemí EU \\ a USA] \\ Jana Hvozdenská ${ }^{1}$ \\ ${ }^{1}$ Masarykova univerzita, Ekonomicko-správní fakulta, Lipová 41a, 60200 Brno \\ Email:174974@mail.muni.cz
}

\begin{abstract}
The yield curve - specifically the spread between long term and short term interest rates is a valuable forecasting tool. It is simple to use and significantly outperform other financial and macroeconomic indicators in predicting recessions two to six quarters ahead. The steepness of the yield curve should be an excellent indicator of a possible future economic activity. A rise in the short rate tends to flatten the yield curve as well as to slow down real growth the near term. This paper aims to analyze the dependence between slope of the yield curve and an economic activity of selected EU countries and the USA between the years 2000 and 2014. The slope of the yield curve can be measured as the yield spread between sovereign 10-year bonds and sovereign 3-month bonds. The natural and probably the most popular measure of economic growth is GDP growth, taken quarterly. The results showed that the best predictive lags are lag of four and five quarters. The results presented also confirm that 10-year and 3-month yield spread has significant predictive power to real GDP growth after financial crisis. These findings can be beneficial for investors and provide further evidence of the potential usefulness of the yield curve spreads as indicators of the future economic activity.
\end{abstract}

Keywords: GDP prediction, slope, spread, yield curve.

JEL classification: E43, E44, E47, G01

Doručeno redakci: 23.2.2015; Recenzováno: 26.2.2015; 8.3.2015; Schváleno k publikování: 27.5.2015

\section{Introduction}

The yield curve simply plots the yield of the bond against its time to maturity. Many market observes carefully track the yield curve's shape, which is typically upward sloping and convex. However when the yield curve becomes flat or slopes downward (the spread between sovereign 10-year and 3-month bond is negative) it may signal GDP decrease (recession).

The yield curve - specifically the spread between long term and short term interest rates is a valuable forecasting tool. It is simple to use and significantly outperform other financial and macroeconomic indicators in predicting recessions two to six quarters ahead.

Widespread use of the yield curve makes assessing its accuracy a worthwhile exercise for economists. But policymakers, too, need an accurate and timely predictor of future economic growth.

With sophisticated macroeconometric models and highly paid professional forecasters, is there any place for a simple indicator like the yield curve? Aside from the knowledge gained about the curve itself, there are several reasons to answer that question affirmatively. Simple predictions may serve as a check on more complex models, perhaps highlighting when assumptions or relationships need rethinking. Agreement between predictions increases confidence in the results, while disagreement signals the need for a second look. A simple, popular indicator also provides some insight into market sentiment. It is always a good idea to 
check whether the expensive and complicated forecasts actually do perform better. After first reviewing some basics about the yield curve and the reasons it might predict future growth, we look at the actual relationship (Haubrich and Dombrosky, 1996).

This paper builds on a wide range of previous researches, but differs in some ways. Bernard and Gerlach (1998) in their paper showed empirically on eight countries that the slope of the yield curve is a good predictor of the real economic activity. Berk and van Bergeijk (2001) examined 12 euro-area countries over the period of 1970-1998 and found that the term spread contains only limited information about future output growth. Their work is based on the previous theoretical researches of Estrella and Hardouvelis (1991), Estrella and Mishkin (1996). There was proven the evidence that the slope of the yield curve and the future GDP activity are related together. However it is necessary to say that this rule was true until the end of 20th century and it mostly disappeared at the beginning of 21 st century and appeared again during the financial crisis (from 2008) and later on (De Pace, 2011; Giacomini and Rossi, 2006; Chinn and Kucko, 2010). Most of the studies are focused on the relationship of the yield curve and GDP activity of the United States of America.

The aim of this paper is to show if the yield spread possesses the predictive power of future economic activity in selected EU countries and the USA and to examine which time lag of the spread is the best for prediction of the future GDP.

Despite various researches, there is not any comprehensive theory that would prove the correlation between the yield spread and economic development of the country yet. We often come across the statements that have only theoretical basis without generally valid empirical evidence. Economic models are largely based on the argument that the yield curve tends to be flatter in the situation of the tight monetary policy and the economic slowdown typically occurs with a slight time lag (Szarowská, 2013).

Almost perfect tool containing the relevant future data provides the yield spread of government bonds. The simplest interpretation of the yield spread is through monetary policy of the country. Based on this criterion - relatively low spread reflects the restrictive and tight monetary policy and vice versa - high spread reflects loose monetary policy. We can find the theoretical justification for using of the spread in expectations hypothesis. It assumes that a long term rate of return is the average of the current and expected future short term yields. The investor's decision to invest in short term or long term asset is completely irrelevant (Mishkin, 1990).

Dependence of the yield spread and GDP can be derived from their connection to the monetary policy of the state. As bond yields react to monetary policy as well as monetary policy is able to respond to the output of the economy, the yield curve assumes overlapping of policy measures and responses. The yield curve has the ability to reflect future production either directly or indirectly. Indirectly it comes to predicting of the future interest rate and the future monetary policy. It may also reflect the future production directly because the 10-year yields may depend on estimates of the output of the economy in 10 years.

A question arises - how many months, quarters, years of future economic activity can be predicted by the yield spread? Based on the study of Bonser-Neal and Morley (1997) as well as Chinn and Kucko (2010) spread has the greatest ability in predicting one-year horizon (four quarters ahead). As it was mentioned above, to prove if the spread has the best predictive power in one-year horizon is one of the aims of this paper. 


\section{Methodology and data}

There are many ways of using the yield curve to predict the future real activity. One common method uses inversions (when short term rates are higher than long term rates) as recession indicators. Obtaining predictions from the yield curve requires a lot of preliminary work. There is the principle which needs to be held: keep the process as simple as possible.

A yield curve may be flat, up-sloping, down-sloping or humped. The standard solution uses a spread (difference between two rates). The problem is to choose the spread between the right terms. The most used spread is between 10-year and 3-month bonds. The problem is that there are rarely bonds which mature exactly in 10 years (or 3 months). In that case the best solution is to use the yield curve, which shows the yield of each maturity. Creating and calculating of the yield curve is a rather difficult task because there are many ways how to do it and every country uses a different model of construction.

The yield curves are constructed by Bloomberg, therefore the data for spreads were gained from Bloomberg. For the spreads 10-year government bond rates minus 3-month sovereign bond rates were chosen (Estrella and Hardouvelis, 1991; Estrella and Mishkin, 1996). Quarterly data were used for the spreads because the data of the economic activity are taken on quarterly basis as well. The data of real GDP can be found at Eurostat, OECD statistics or Bloomberg. The data of real GDP obtained and used in this paper are from OECD statistics.

The selected countries are countries of EU-28 (Austria, Belgium, Bulgaria, Croatia, Cyprus, the Czech Republic, Denmark, Estonia, Finland, France, Germany, Greece, Hungary, Ireland, Italy, Latvia, Lithuania, Luxembourg, Malta, the Netherlands, Poland, Portugal, Romania, Slovakia, Slovenia, Spain, Sweden, the United Kingdom) and the USA. Unfortunately there were no data for Croatia, Cyprus, Estonia, Latvia, Lithuania and Romania available, therefore we had to omit these countries. The dataset of Malta was available only from 3Q2008 to 3Q2014.

There is no previous research which would prove or reject the hypothesis of real GDP and bond spread dependence in European countries.

As a measure of real growth four-quarter percent change in real GDP was used (thus the percent change of the quarter against the last year's same quarter was calculated, e.g. the change from 1Q2004 and 1Q2003 real GDP was used). GDP is standard measure of aggregate economic activity and the four-quarter horizon answers the frequently asked question - what happens the next year?

The sample period starts from 1Q2000 and ends on 3Q2014. This time range covers the period before financial crisis, period of financial crisis and period after financial crisis. The basic model is designed to predict real GDP growth/decrease two to six quarters into the future based on the current yield spread (Bonser-Neal and Morley, 1997).

This was accomplished by running of a series of regressions using real GDP activity and the spread between 10-year and 3-month bond yields lagged two to six quarters (e.g. if the spread was lagged by 4 quarters, the interest rate spread used for 3Q2001 is actually from 3Q2000). The last step is to find out which spread lag is the best for which country and to prove the hypothesis that the lag of four quarters is the best one for prediction of future GDP growth. 
To generate the GDP predictions the regression using the whole sample was run, and later on two divided samples of real GDP and spreads of each selected country (the sample is divided in 4Q2007/1Q2008, because this period preceded financial crisis and should show some changes in prediction of the yield curve spread) were run.

The coefficients $\alpha$ and $\beta$ were estimated for each country:

$$
\text { Real GDP } P_{t+n}=\propto+\beta * \operatorname{spread}_{t}+\varepsilon_{t}
$$

Where:

Real GDPt $+n$ is a prediction of the future real GDP in time $t+n$

$n$ is the lag of spread, value of the lag can be 2, 3, 4, 5 or 6

spread $_{t}$ is spread between 10-year and 3-month state bonds in time $\mathrm{t}$

$\varepsilon_{t}$ is a white noise

\section{Results and discussion}

The whole sample of dataset contains the real GDP from 1Q2000 to 3Q2014. A regression of the whole sample was run and we got the results as seen in Table 1.

Table 1: Results of all countries and whole sample from OLS regression

\begin{tabular}{|c|c|c|c|c|}
\hline 1Q00 $-\mathbf{3 Q 1 4}$ & Constant & Spread & $\mathbf{P}-$ value (F - test) & $\mathbf{R}^{\mathbf{2}}$ \\
\hline Austria $\mathrm{n}=5$ & 0.00392699 & 0.835224 & $0.0021 * * *$ & 0.153549 \\
\hline Belgium $\mathrm{n}=4$ & 0.00892386 & 0.253578 & 0.2992 & 0.018896 \\
\hline Bulgaria $\mathrm{n}=6$ & 0.0186799 & 0.628145 & $0.0018 * * *$ & 0.158618 \\
\hline Czech Rep. $\mathrm{n}=2$ & 0.0339965 & -0.347492 & 0.5145 & 0.007493 \\
\hline Denmark $\mathrm{n}=4$ & -0.0079170 & 1.17141 & $0.0016 * * *$ & 0.161495 \\
\hline Finland $\mathrm{n}=5$ & -0.0099475 & 1.93101 & $0.0001 * * *$ & 0.227732 \\
\hline France $\mathrm{n}=5$ & 0.00427149 & 0.442720 & 0.0834 & 0.051648 \\
\hline Germany $\mathrm{n}=5$ & -0.0037077 & 1.08377 & $0.0059 * * *$ & 0.125750 \\
\hline Greece $\mathrm{n}=2$ & 0.0494464 & -0.595524 & $2.62 \mathrm{e}-08 * * *$ & 0.421816 \\
\hline Hungary $\mathrm{n}=6$ & 0.0129305 & -0.776075 & $8.13 \mathrm{e}-05 * * *$ & 0.240243 \\
\hline Ireland $\mathrm{n}=2$ & 0.0335926 & -0.350539 & 0.1010 & 0.046483 \\
\hline Italy $\mathrm{n}=2$ & 0.0192736 & -0.748919 & $0.0024 * * *$ & 0.150165 \\
\hline Luxembourg $\mathrm{n}=6$ & 0.0279051 & 0.703821 & 0.1433 & 0.037197 \\
\hline Malta $\mathrm{n}=4$ & -0.0106991 & 1.27180 & $0.0217 * *$ & 0.208677 \\
\hline Netherlands $\mathrm{n}=2$ & 0.0331701 & -1.32837 & $1.11 \mathrm{e}-05 * * *$ & 0.289354 \\
\hline Poland $\mathrm{n}=4$ & 0.0379799 & 0.243271 & $0.0043 * * *$ & 0.134113 \\
\hline Portugal $\mathrm{n}=2$ & 0.0134541 & -0.423174 & $0.0149 * *$ & 0.099645 \\
\hline Slovakia $\mathrm{n}=2$ & 0.0598837 & -1.49028 & $8.77 \mathrm{e}-05 * * *$ & 0.238328 \\
\hline Slovenia $\mathrm{n}=2$ & 0.0312604 & -0.776240 & 0.0524 & 0.064425 \\
\hline Spain $\mathrm{n}=2$ & 0.0379462 & -1.09437 & $3.75 \mathrm{e}-07 * * *$ & 0.366670 \\
\hline Sweden $\mathrm{n}=4$ & -0.0132704 & 2.51857 & $4.64 \mathrm{e}-012 * * *$ & 0.570886 \\
\hline United Kingdom $\mathrm{n}=5$ & 0.00283286 & 0.741750 & 0.0830 & 0.051806 \\
\hline USA $\mathrm{n}=6$ & 0.00939793 & 0.575424 & $0.0029 * * *$ & 0.145038 \\
\hline
\end{tabular}

Source: author's own calculation in Gretl, data of government bond spreads obtained from terminal Bloomberg, data of real GDP obtained from OECD statistics 
Surprisingly we got the best results of the models mostly for lag of spreads 2 (Greece, Italy, the Netherlands, Portugal, Slovakia, Spain). The lag of spreads 4 is the second best choice (Denmark, Malta, Poland, Sweden). And the third best was the lag of spreads 5 (Austria, Finland, Germany).

We can say that models for Austria, Bulgaria, Denmark, Finland, Germany, Greece, Hungary, Italy, Malta, the Netherlands, Poland, Portugal, Slovakia, Spain, Sweden and the USA are statistically significant, because the p-values are under $1 \%(* * *)$ or $5 \%(* *)$, however the $\mathrm{R}^{2}$ are not very high except of Finland, Greece, Hungary, Malta, the Netherlands, Slovakia, Spain and Sweden.

The $\mathrm{R}^{2}$ coefficients (coefficients of determination) show us how many percent of the sample can be explained by these models.

Models for countries mentioned above may be used as predictive models.

The model for Belgium, the Czech Republic, France, Ireland, Luxembourg, Slovenia and the United Kingdom cannot be used as predictive due to their high $\mathrm{p}$-value and very low $\mathrm{R}^{2}$.

For example we can say that future real GDP of Austria will be:

Real GDP Austria $\mathrm{t}+5=-0.00392699+0.835224 * \operatorname{spread}_{\text {Austria } \mathrm{t}}$

By this model we can predict future real gross domestic product for Austria five quarters ahead.

We can test the hypothesis that the behavior of the spread and gross domestic product has changed during the financial crisis, therefore the sample was divided into two samples in order to prove this hypothesis.

\subsection{Results of regression - divided samples}

The research continued as follows - the whole sample was divided into two samples. The first one is from 1Q2000 to 4Q2007, the second one is from 1Q2008 to 3Q2014 in order to show if there is any change of behavior and dependency between the variables before or after the financial crisis.

Regressions of the first sample and the second sample were run. The results for the time span of 1Q2000 - 4Q2007 (first sample) are possible to see in Table 2, the results for the period of 1Q2008 - 3Q2014 (second sample) are in Table 3.

In the first period the best results were gained with lag of spreads by 6 quarters (Austria, Finland, Hungary, Italy, the Netherlands, Portugal, Slovenia and the USA). The second best results we got for the lag of spreads by 4 quarters (Denmark, Greece, Ireland, Luxembourg, Slovakia).

We can say that the models for Belgium, Bulgaria, the Czech Republic, Denmark, Greece, Hungary, Ireland, Luxembourg, the Netherlands, Poland, Slovakia, Slovenia, Spain, Sweden, the United Kingdom and the USA may be used as predictive, because their p-value is under $5 \%(* *)$. 
Again the $\mathrm{R}^{2}$ are not very high except for Bulgaria, the Czech Republic, Greece, Hungary, Poland, Spain, Sweden and the USA.

Models for Austria, Finland, France, Germany, Italy and Portugal cannot be used as predictive models, because of their high $\mathrm{p}$-values and very low $\mathrm{R}^{2}$.

Table 2: Results of all countries and sample from 1Q2000 to 4Q2007

\begin{tabular}{|c|c|c|c|c|}
\hline $1 Q 00-4 Q 07$ & Constant & Spread & $\begin{array}{l}\mathbf{P} \text { - value } \\
(\mathbf{F}-\text { test })\end{array}$ & $\mathbf{R}^{2}$ \\
\hline Austria $n=6$ & 0.0307787 & -0.455781 & 0.1763 & 0.060084 \\
\hline Belgium $n=3$ & 0.00940078 & 0.789470 & $0.0171 * *$ & 0.175160 \\
\hline Bulgaria $n=2$ & 0.0675536 & -0.382749 & $0.0023 \quad * * *$ & 0.269139 \\
\hline Czech Rep. $n=5$ & 0.0185649 & 1.83205 & $2.76 \mathrm{e}-05 * * *$ & 0.448581 \\
\hline Denmark $n=4$ & 0.00896117 & 0.686048 & $0.054216 * *$ & 0.118022 \\
\hline Finland $n=6$ & 0.0402452 & -0.361997 & 0.4042 & 0.023303 \\
\hline France $n=3$ & 0.0132341 & 0.512490 & 0.0610 & 0.112158 \\
\hline Germany $n=2$ & 0.0258136 & -0.714181 & 0.1058 & 0.084827 \\
\hline Greece $n=4$ & 0.0824349 & -0.944996 & $0.000900 * * *$ & 0.311635 \\
\hline Hungary $n=6$ & 0.0218873 & -0.70094 & $1.88 \mathrm{e}-06 * * *$ & 0.536513 \\
\hline Ireland $n=4$ & 0.0362481 & 1.06149 & $0.033029 * *$ & 0.142717 \\
\hline Italy $n=6$ & 0.0193113 & -0.365716 & 0.2460 & 0.044581 \\
\hline Luxembourg $n=4$ & 0.0414236 & 0.727023 & $0.050328 * *$ & 0.121733 \\
\hline Malta & $\mathrm{x}$ & $\mathrm{x}$ & $\mathrm{x}$ & $\mathrm{x}$ \\
\hline Netherlands $n=6$ & 0.0140177 & 0.452712 & $0.0405 * *$ & 0.132546 \\
\hline Poland $n=5$ & 0.0514526 & 0.474488 & $2.06 \mathrm{e}-06 * * *$ & 0.533742 \\
\hline Portugal $n=6$ & 0.0268181 & -0.793569 & 0.0684 & 0.106410 \\
\hline Slovakia $n=4$ & 0.0670920 & -1.35016 & $0.0093 \quad * * *$ & 0.204940 \\
\hline Slovenia $n=6$ & 0.0518221 & -0.652960 & $0.0303 \quad * *$ & 0.147055 \\
\hline Spain $n=2$ & 0.0409743 & -0.608141 & $0.0004 \quad * * *$ & 0.341136 \\
\hline Sweden $n=3$ & 0.0127549 & 1.24421 & $0.0005 * * *$ & 0.339790 \\
\hline United Kingdom $n=3$ & 0.0217436 & 0.513701 & $0.0118 * *$ & 0.193272 \\
\hline USA $n=6$ & 0.0179499 & 0.535402 & $0.0015 \quad * * *$ & 0.289367 \\
\hline
\end{tabular}

Source: author's own calculation in Gretl, data of government bond spreads obtained from terminal Bloomberg, data of real GDP obtained from OECD statistics

In the second period the best results were gained by lag of spreads by 5 quarters, the second best results we got with the lag of 4 quarters. All models except for the models for the Netherlands, Portugal, Slovakia, Slovenia and Spain can be used as predictive and we got much better results from most of the countries. $\mathrm{R}^{2}$ of Austria, Denmark, Finland, France, Germany and Sweden are higher than $40 \%$ which is very good.

This change in prediction possibility may be caused by different behavior of financial markets after the financial crisis (after year 2008). 
Table 3: Results of all countries and sample from 1Q2008 to 4Q2013

\begin{tabular}{|c|c|c|c|c|}
\hline $1 Q 08-4 Q 13$ & Constant & Spread & $\begin{array}{l}P \text { - value } \\
(\mathbf{F} \text { - test })\end{array}$ & $\mathbf{R}^{2}$ \\
\hline Austria $n=5$ & -0.013 & 1.23265 & $9.07 \mathrm{e}-05 * * *$ & 0.464523 \\
\hline Belgium $n=4$ & -0.01277 & 0.745299 & $0.0195 * *$ & 0.199633 \\
\hline Bulgaria $n=6$ & -0.0062487 & 0.933633 & $0.0162 * *$ & 0.20992 \\
\hline Czech Rep. $n=4$ & -0.02387 & 1.27710 & $0.0366 * *$ & 0.163226 \\
\hline Denmark $n=5$ & -0.03315 & 2.09861 & $0.0002 * * *$ & 0.442244 \\
\hline Finland $n=5$ & -0.04071 & 2.55453 & $2.57 \mathrm{e}-05 * * *$ & 0.514106 \\
\hline France $n=5$ & -0.02207 & 1.16414 & $0.0001 * * *$ & 0.452340 \\
\hline Germany $n=5$ & -0.03102 & 2.30405 & $0.0002 * * *$ & 0.439579 \\
\hline Greece $n=2$ & 0.0002547 & -0.335482 & $0.0008 * * *$ & 0.369159 \\
\hline Hungary $n=2$ & -0.01589 & 1.25960 & $0.0213 * *$ & 0.194432 \\
\hline Ireland $n=4$ & -0.02888 & 0.612569 & $0.0047 * * *$ & 0.277797 \\
\hline Italy $n=5$ & -0.03444 & 0.745154 & $0.0172 * *$ & 0.206746 \\
\hline Luxembourg $n=3$ & 0.00111139 & 3.13188 & $0.0059 * * *$ & 0.265790 \\
\hline Malta $n=4$ & -0.0106991 & 1.27180 & $0.0217 * *$ & 0.208677 \\
\hline Netherlands $n=5$ & -0.0118355 & 0.544089 & 0.2048 & 0.063495 \\
\hline Poland $n=4$ & 0.0192019 & 1.00260 & $0.0044 * * *$ & 0.282251 \\
\hline Portugal $n=5$ & -0.0198834 & 0.389921 & 0.0620 & 0.132423 \\
\hline Slovakia $n=4$ & -0.0004261 & 0.991022 & 0.1014 & 0.103730 \\
\hline Slovenia $n=5$ & -0.0180976 & 0.796055 & 0.1592 & 0.077671 \\
\hline Spain $n=6$ & -0.0159121 & 0.330497 & 0.1353 & 0.086996 \\
\hline Sweden $n=4$ & -0.0225111 & 2.75388 & $2.61 \mathrm{e}-07 * * *$ & 0.660520 \\
\hline United Kingdom $n=5$ & -0.0268710 & 1.34084 & $0.0397 * *$ & 0.158473 \\
\hline USA $n=6$ & -0.0061863 & 0.885591 & $0.0080 * * *$ & 0.249557 \\
\hline
\end{tabular}

Source: author's own calculation in Gretl, data of government bond spreads obtained from terminal Bloomberg, data of real GDP obtained from OECD statistics

The best predictive models are as follows:

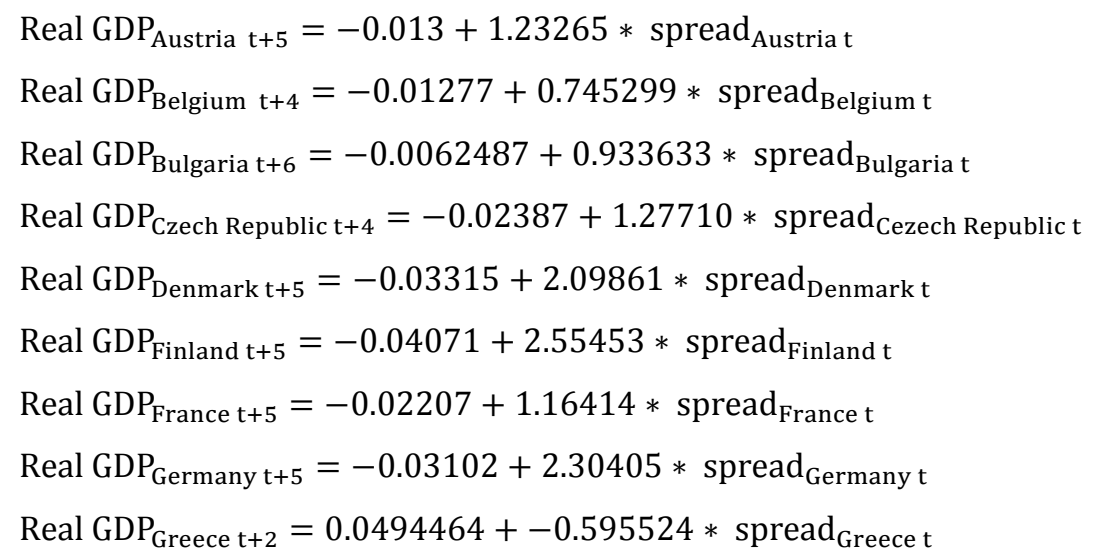




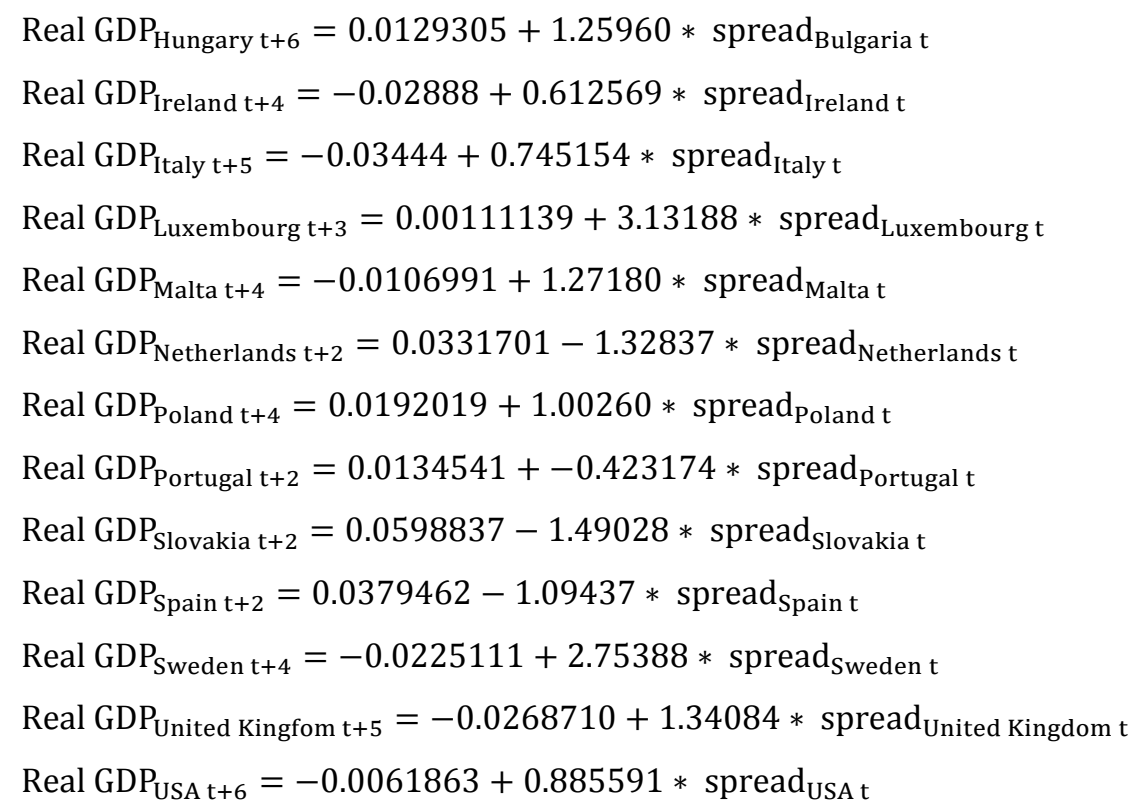

For example if there would be a change of $1 \%$ up in the spread of Austria then the GDP would increase about $1.123 \%(-0.013+1.123265 * 1 \%)$.

The best model for Greece, Hungary, the Netherlands, Portugal and Slovakia - are taken from the whole sample (1Q2000 - 3Q2014). All the other models are taken from the divided sample (1Q2008 - 3Q2014).

At the end we can summarize the findings and predict the future GDP of the selected countries.

\subsection{Prediction of GDP growth}

The spreads are known from the year 2014. The predictions of GDP growth are in Table 4.

The GDP of Austria, Belgium, the Czech Republic, Finland, France, Germany and the United Kingdom should rise and later on decrease. The GDP of Bulgaria, Greece, Hungary, Luxembourg, Malta, the Netherlands, Poland, Slovakia, Sweden and the United States should rise in the observed periods. The GDP of Ireland, Italy and Portugal should decrease. The GDP of Spain should decrease and later on increase. 
Table 4: Prediction of GDP growth in the selected countries

\begin{tabular}{|c|c|c|c|c|c|c|}
\hline & 4Q2014 & 1Q2015 & 2Q2015 & 3Q2015 & 4Q2015 & 1Q2016 \\
\hline AUS spread & 0.02052 & 0.01612 & 0.01517 & 0.01176 & 0.00668 & \\
\hline AUS GDP & 0.012294 & 0.0068703 & 0.0057 & 0.001496 & -0.004766 & \\
\hline BEL spread & 0.02497 & 0.02024 & 0.01696 & 0.01255 & & \\
\hline BEL GDP & 0.00584 & 0.0023149 & -0.0001 & -0.003416 & & \\
\hline BUL spread & 0.029471 & 0.030021 & 0.02715 & 0.028811 & 0.030472 & 0.032133 \\
\hline BUL GDP & 0.021266 & 0.0217799 & 0.0191 & 0.0206502 & 0.022201 & 0.0237517 \\
\hline CZE spread & 0.024335 & 0.021245 & 0.0136 & 0.011263 & & \\
\hline CZE GDP & 0.007208 & 0.003262 & -0.0065 & -0.009486 & & \\
\hline DEN spread & 0.01975 & 0.01619 & 0.01618 & 0.01149 & 0.00929 & \\
\hline DEN GDP & 0.008298 & 0.0008265 & 0.00081 & -0.009037 & -0.013654 & \\
\hline FIN spread & 0.01979 & 0.0171 & 0.01398 & 0.01111 & 0.00637 & \\
\hline FIN GDP & 0.009844 & 0.0029725 & -0.005 & -0.012329 & -0.024438 & \\
\hline FRA spread & 0.024127 & 0.018947 & 0.01677 & 0.01315 & 0.008786 & \\
\hline FRA GDP & 0.006017 & $-1.3 \mathrm{E}-05$ & -0.0026 & -0.006762 & -0.011842 & \\
\hline GER spread & 0.01844 & 0.01519 & 0.01276 & 0.01038 & 0.00705 & \\
\hline GER GDP & 0.011467 & 0.0039785 & -0.0016 & -0.007104 & -0.014776 & \\
\hline GREECE spread & 0.06499 & 0.04191 & & & & \\
\hline GREECE GDP & 0.010743 & 0.024488 & & & & \\
\hline HUN spread & 0.027 & 0.0275 & 0.0215 & 0.0327 & 0.0207 & 0.0126 \\
\hline HUN GDP & 0.046402 & 0.0470321 & 0.03947 & 0.053582 & 0.038467 & 0.028264 \\
\hline IRE spread & 0.03295 & 0.02622 & 0.02143 & 0.01592 & & \\
\hline IRE GDP & -0.0087 & -0.012818 & -0.0158 & -0.019128 & & \\
\hline ITA spread & 0.03483 & 0.02877 & 0.02662 & 0.02225 & 0.01776 & \\
\hline ITA GDP & -0.00849 & -0.013002 & -0.0146 & -0.01786 & -0.021206 & \\
\hline LUX spread & 0.0208 & 0.0191 & 0.0157 & & & \\
\hline LUX GDP & 0.066254 & 0.0609303 & 0.05028 & & & \\
\hline MAL spread & 0.02935 & 0.02754 & 0.02513 & 0.0216 & & \\
\hline MAL GDP & 0.026628 & 0.0243263 & 0.02126 & 0.0167718 & & \\
\hline NET spread & 0.02234 & 0.01792 & & & & \\
\hline NET GDP & 0.003494 & 0.0093657 & & & & \\
\hline POL spread & 0.020748 & 0.017875 & 0.01125 & 0.011431 & & \\
\hline POL GDP & 0.040004 & 0.0371234 & 0.03048 & 0.0306626 & & \\
\hline POR spread & 0.046857 & 0.044252 & & & & \\
\hline POR GDP & -0.00637 & -0.005272 & & & & \\
\hline SK spread & 0.020666 & 0.018661 & & & & \\
\hline SK GDP & 0.029086 & 0.0320736 & & & & \\
\hline SPA spread & 0.03523 & 0.02906 & & & & \\
\hline SPA GDP & -0.00061 & 0.0061438 & & & & \\
\hline SWE spread & 0.01764 & 0.01368 & 0.01288 & 0.01298 & & \\
\hline SWE GDP & 0.026067 & 0.015162 & 0.01296 & 0.0132343 & & \\
\hline UK spread & 0.02672 & 0.02295 & 0.02232 & 0.01953 & 0.01292 & \\
\hline UK GDP & 0.008956 & 0.0039013 & 0.00306 & -0.000684 & -0.009547 & \\
\hline USA spread & 0.029623 & 0.026876 & 0.0251 & 0.024736 & 0.021357 & 0.018069 \\
\hline USA GDP & 0.020048 & 0.0176148 & 0.01604 & 0.0157197 & 0.012727 & 0.0098154 \\
\hline
\end{tabular}

Source: author's own calculation, data of government bond spreads obtained from terminal Bloomberg, data of real GDP obtained from OECD statistics 
At the end we can summarize the new theoretical finding according to which lag of spread is the best for predicting of the future GDP. We proved that in these selected countries the best lag of spreads are lag 4 and lag 5. These lags show the best results in the models of the divided period - after financial crisis. The results show that the dividing of the sample made a difference between pre-crisis and after-crisis period and it showed bigger influence of spreads on predicting of the future GDP. The finding that the best lags of spreads are four and five confirm the theoretical background which says that the lag of four quarter is the best for the GDP prediction in the United States of America (from 1970 to 2000).

\section{Conclusions}

Does the yield curve accurately predict the real economic growth? Answering this seemingly simple question requires a surprising amount of preliminary work. The 10-year - 3-month spread has substantial predictive power and should provide good forecast of real growth two to six quarters into the future. We showed that the best predictive lags of spreads are lags of four and five quarters in order to get the best results for predictive models. The results presented above confirm that 10-year and 3-month yield spread has a significant predictive power for real GDP growth and the behavior of the models changed during and after the financial crisis. The results show that the dividing of the sample made a difference between pre-crisis and after-crisis period and it showed bigger influence of spreads on predicting of the future GDP.

The simple yield curve growth forecast should not serve as a replacement for the predictions of companies, which deal with predicting of many economic indicators, it however does provide enough information to serve as a useful check on the more sophisticated forecasts.

Future research could be extended to a wider examination of the best lags of spreads in more countries around the world. It would be interesting to see if there is any rule which would prove the hypothesis that lag of four and five quarters is the best for predicting future GDP growth in the countries out of the European Union (it was empirically proved that in the USA during 1970 and 2000 the best lag of spread was a lag of 4 quarters).

\section{Acknowledgement}

Support of Masaryk University within the project MUNI/A/1127/2014 "Analysis, development and testing of models of financial valuation, hedging and investment assets and the use for prediction the financial crisis" is gratefully acknowledged.

\section{Literature}

[1] BERK, J. and P. VAN BERGEIJIK, 2001. On the Information Content of the Yield Curve: Lessons for the Eurosystem? Kredit und Kapital, 34(1), 28-47. ISSN 0023-4591.

[2] BERNARD, H. J. and S. GERLACH, 1998. Does the Term Structure Predict Recessions? The International Evidence. CEPR Discussion Paper Series, 1892.

[3] BLOOMBERG, 2015. 10-year, 3-month government bond yields. Terminal Bloomberg.

[4] BONSER-NEAL, C. a T. R. MORLEY, 1997. Does the Yield Spread Predict Real Economic Activity? A Multicountry Analysis. Economic Review: Federal Reserve Bank of Kansas City, 82(3), 37-53. ISSN 0161-2387.

[5] CHINN, M. and K. KUCKO, 2010. The predictive power of the yield curve across countries and time. NBER Working Paper Series, 16398. Available from: http://www.nber.org/papers/w16398 
[6] DE PACE, P., 2011. GDP Growth Predictions through the Yield Spread: Time Variation and structural Breaks. Euro Area Business Cycle Network. Available from: http://papers.ssrn.com/sol3/papers.cfm?abstract_id=1401752

[7] ESTRELLA, A. and G. A. HARDOUVELIS, 1991. The Term Structure as a Predictor of Real Economic Activity. Journal of Finance, 46(2), 555-576. DOI: 10.1111/j.15406261.1991.tb02674.x

[8] ESTRELLA, A. and F. S. MISHKIN, 1996. The Yield Curve as a Predictor of U.S. Recessions. Current Issues in Economics and Finance, 2(7). FR Bank of New York. Available from: www.ny.frb.org/research/current_issues/ci2-7.pdf

[9] GIACOMINI, R. and B. ROSSI, 2006. How stable is the Forecasting Performance of the Yield Curve for Output Growth. Los Angeles: Duke University and University of California. DOI: 10.1111/j.1468-0084.2006.00456.x

[10] HAUBRICH, J. and A. DOMBROSKY, 1996. Predicting Real Growth Using the Yield Curve. Economic Review: Federal Reserve Bank of Cleveland, 32(1), 26-35. Available from: lamfin.arizona.edu/fixi/jhaub.pdf

[11] MISHKIN, F., 1990. Yield curve. NBER Working Papers Series, No. 3550. DOI: $10.3386 / \mathrm{w} 3550$

[12] OECD STATISTICS, 2015. Quarterly national accounts: Quarterly Growth rates of real GDP, change over previous quarter. OECD statistics [online]. [cit. 2015-02-09]. Available at : http://stats.oecd.org/index.aspx?queryid $=350$

[13] SZAROWSKÁ, I., 2013. Fiscal Discipline as a Driver of Sovereign Risk Spread in the European Union Countries. In: 22nd IBIMA Conference on Creating Global Competitive Economies: 2020 Vision Planning \& Implementation. Rome: IBIMA, 793-804. ISBN 978-0-9860419-1-4. 